Research Article

\title{
Effect of Antiepileptic drugs on lipid profile in children with Epilepsy
}

\author{
Nadkarni $\mathbf{J}^{1}$, Uikey $\mathbf{D}^{2}$, Sharma $\mathbf{U}^{3}$, Dwivedi $\mathbf{R}^{4}$ \\ ${ }^{1}$ Dr Jayashree Nadkarni, Associate Professor, ${ }^{2}$ Dr Deepak Kumar Uikey, Senior Resident, ${ }^{3}$ Dr Utkarsh Sharma, Intern, \\ ${ }^{4}$ Dr Rashmi Dwivedi, Professor and Head, Department of Paediatrics. All are affiliated with Gandhi Medical College and \\ Associated Kamla Nehru Hospital, Bhopal (M.P), India 462016
}

Address for correspondence: Dr. Jayashree Nadkarni, Email: jayadn2007@gmail.com

\begin{abstract}
Objective: The study evaluated the effect of antiepileptic drugs on lipid profile in children with epilepsy. Demographic profileand the seizure pattern of CWE were also studied. Material and method: 95 children aged between 2-15 years with confirmed diagnosis of primary epilepsy who were on AED for at least 3months were the cases and 50 normal healthy children of similar age group were the controls. Children with BMI $>95^{\text {th }}$ centile were excluded. The cases were categorized in three groups depending upon whether they were taking either phenytoin, valproic acid alone or in combination. Results: The Levene's test for homogeneity of variance indicated a significant difference in variance between the cases and control group in serum TGs, LDL-C and VLDL-C. The t-test showed a significant difference in means among cases and controls in HDL-C, LDL-C levels and the risk ratio. Conclusion: We recommend a need for careful monitoring of lipid profile in children with epilepsy receiving antiepileptic drugs.
\end{abstract}

Key Words- AED, CWE, Lipid profile, Seizures, Phenytoin, Valproic acid

\section{Introduction}

Epilepsy imposes a large economic burden on health care systems of countries. Approximately, 70-80 \% of patients who develop epilepsy may expect to have their seizures controlled with optimal antiepileptic therapy [1]. Population based studies report prevalence rate 3.6 to 4.2 per 1000 for children in developed countries $[2,3]$ and approximately double these rates in developing countries [4-6].

The potential for adverse events due to antiepileptic drugs in children is greater than in adults because young children have immature detoxification mechanisms and a greater variability in dosing owing to a wider range of body size and weight [7].

Few data are available defining adverse effects in children because clinical trials for paediatric use of AEDs are generally small and mainly focus on efficacy [8]. In this study, we observed the effect of AEDs on lipid profile in children with epilepsy.

\section{Material and Methods}

This observational cross-sectional study was conducted in

Manuscript received: $18^{\text {th }}$ Feb 2014

Reviewed: $25^{\text {th }}$ Feb 2014

Author Corrected: $23^{\text {th }}$ Mar 2014

Accepted for Publication: $29^{\text {th }}$ Mar 2014 the Department of Paediatrics of a tertiary level teaching hospital in central India. Children with epilepsy who were admitted as well those attending the outpatient department were the cases. Study duration was of one year. Only children with confirmed diagnosis of Primary/Idiopathic epilepsy were included. Their ages were between 2-15 years. These children were taking antiepileptics for at least 3 months. Children with BMI $>95^{\text {th }}$ centiles were not included in the study.

Age matched healthy controls were taken from the outpatient department. An informed consent was obtained from parents or guardians after explaining the nature and purpose of the study. Details of history and examination were entered in a predesigned proforma.

\section{Sample collection}

With all aseptic precautions, $2 \mathrm{ml}$ venous blood was drawn from peripheral vein, in a non-EDTA bulb. Sample was collected after 8-10 hours fasting in both cases and controls. Serum was analysed for lipid profile by an autoanalyzer (BIOSYSTEM A-25) for triglycerides and total cholesterol. High density lipoprotein was determined using Autozyme HDL-cholesterol precipitating reagent. Very low-density 
lipoproteins (VLDL) and LDL-C were calculated using Friedewald formula ${ }^{9}$ i.e., $\mathrm{LDL}$ cholesterol $=\mathrm{TC}-\mathrm{HDL}$ $\mathrm{TG} / 5.0(\mathrm{mg} / \mathrm{dL})$.

\section{Statistical method and analysis}

All analysis was conducted using SPSS-16 (Statistical Package For Social Science). All mean was expressed as mean \pm SD. The comparisons within the groups (i.e. Phenytoin, Valproic acid and combination group) and between the groups (i.e. between phenytoin and valproic acid, combination and valproic acid, \& between combination and phenytoin) was done using Annova with Tukey HSD and Games-Howell.

Appropriate univariate and bivariate analysis was carried out by Levene's Test for Equality of Variances and ttest for Equality of Means and test of significance was $\mathrm{P}<0.05$.

\section{Results}

In the present study, 95 children aged between 2-15 years already diagnosed as primary epilepsy, who were admitted as well those attending outpatient department were the cases and 50 normal healthy children of similar age group were the controls. All epileptic children had been treated for at least 3 months with either phenytoin and valproic acid alone or in combination. Table 1 summarises the demographic and the epilepsy related data of the patients.

Table 1: Demographic and epilepsy related parameters

\begin{tabular}{|l|l|l|l|l|}
\hline Parameter & \multicolumn{1}{|c|}{ Valproic acid } & Phenytoin & Combination & Control \\
\hline Age $($ years \pm SD) & $7.3 \pm 3.1$ & $7.74 \pm 2.56$ & $7 \pm 2.4$ & $6.27 \pm 2.73$ \\
\hline Males: Females & $35: 10$ & $18: 16$ & $7: 9$ & $28: 22$ \\
\hline Weight $(\mathrm{kg})($ mean \pm SD) & $19.6 \pm 6.63$ & $20.03 \pm 5.41$ & $18.06 \pm 5.01$ & $20.9 \pm 5.6$ \\
\hline Height $(\mathrm{cm})($ mean \pm SD) & $112.9 \pm 15.63$ & $114.5 \pm 12.08$ & $111.56 \pm 14.25$ & $118.0 \pm 13.2$ \\
\hline BMI $\left(\mathrm{kg} / \mathrm{m}^{2}\right)($ mean \pm SD) & $15.71 \pm 2.37$ & $15.79 \pm 1.86$ & $15.38 \pm 1.31$ & $14.8 \pm 2.0$ \\
\hline Type of seizure & $36(45.57 \%)$ & $31(39.24 \%)$ & $12(15.19 \%)$ & \\
GTCS & $1(25.00 \%)$ & $0(0.00 \%)$ & $3(75.00 \%)$ & \\
MC & $0(0.00 \%)$ & $1(100.00 \%)$ & $0(0.00 \%)$ & \\
AS & $8(72.73 \%)$ & $2(18.18 \%)$ & $1(9.09 \%)$ & \\
SPS & \multicolumn{2}{|l}{} \\
\hline
\end{tabular}

GTCS - Generalized tonic clonic seizures, MC - Myoclonic seizures, AS-Absence seizures, SPS - simple partial seizures.

Generalized tonic clonic seizures were the commonest type of seizures noted. The mean BMI was $15.68 \pm 2.0$ in between age group 5-15 years. Most of the children with epilepsy in our study belonged to rural areas and the literacy level was higher in their mothers. $73.7 \%$ of their fathers and $53 \%$ of their mothers were illiterate, whereas, $16.8 \%$ of their mothers were educated upto middle class.

Table 2: Comparison of biochemical parameters of lipid profile between cases and controls.

\begin{tabular}{|l|l|l|l|l|}
\hline Parameter & Cases $(\mathbf{n}=\mathbf{9 5})$ & Controls $(\mathbf{n}=\mathbf{5 0})$ & Levene's test & t-test P-value \\
\hline TC $(\mathrm{mg} / \mathrm{dL})$ & $161 \pm 39.4$ & $160 \pm 24.6$ & 0.110 & 0.907 \\
\hline TG $(\mathrm{mg} / \mathrm{dL})$ & $98.4 \pm 41.7$ & $89.3 \pm 23.7$ & 0.004 & 0.154 \\
\hline HDL-C $(\mathrm{mg} / \mathrm{dL})$ & $43.7 \pm 12.5$ & $55.8 \pm 15.2$ & 0.074 & 0.000 \\
\hline LDL-C $(\mathrm{mg} / \mathrm{dL})$ & $97.9 \pm 34.7$ & $87.0 \pm 24.1$ & 0.032 & 0.051 \\
\hline VLDL-C $(\mathrm{mg} / \mathrm{dL})$ & $19.5 \pm 8.3$ & $17.8 \pm 4.6$ & 0.005 & 0.182 \\
\hline RR & $3.83 \pm 1.06$ & $3.0 \pm 0.95$ & 0.078 & 0.000 \\
\hline
\end{tabular}

$\mathrm{TC}=$ Total cholesterol, HDL-C $=$ High density lipoprotein cholestrol,

LDL-C = Low density lipoprotein cholestrol, VLDL-C = Very low density lipoprotein cholestrol, $\mathrm{TG}=\mathrm{Triglycerides,} \mathrm{RR}=\mathrm{Risk}$ ratio (TC/HDL-C) 
It is clear from Tables that there was significant difference in means among cases and controls as regards HDL-C, LDL-C, Risk Ratio was noted (Table 2).

Table 3: Comparison between groups and within groups of individual biochemical parameters

\begin{tabular}{|l|l|l|l|l|l|l|}
\hline & & Sum of Squares & df & Mean Square & F & P value \\
\hline SCH & Between Groups & 367.825 & 2 & 183.912 & .116 & .890 \\
\hline & Within Groups & 145678.533 & 92 & 1583.462 & & \\
\hline & Total & 146046.358 & 94 & & & \\
\hline STRIG & Between Groups & 1543.306 & 2 & 771.653 & .438 & .647 \\
\hline & Within Groups & 162012.315 & 92 & 1761.003 & & \\
\hline & Total & 163555.621 & 94 & & & \\
\hline & Between Groups & 494.472 & 2 & 247.236 & 1.582 & .211 \\
\hline & Within Groups & 14379.317 & 92 & 156.297 & & \\
\hline & Total & 14873.789 & 94 & & & \\
\hline & Between Groups & 1780.007 & 2 & 890.004 & .733 & .483 \\
\hline & Within Groups & 111637.319 & 92 & 1213.449 & & \\
\hline & Total & 113417.326 & 94 & & & \\
\hline & Between Groups & 61.330 & 2 & 30.665 & .439 & .646 \\
\hline & Within Groups & 6428.417 & 92 & 69.874 & & \\
\hline & Total & 6489.747 & 94 & & & \\
\hline
\end{tabular}

$\mathrm{SCH}=$ Total cholesterol, STRIG =Serum Triglycerides, HDL-C $=$ High density lipoprotein cholesterol, LDL-C $=$ Low density lipoprotein cholestrol, VLDL-C = Very low density lipoprotein cholesterol, df=Degree of freedom, F=F-Value

From table 3 it is seen that there was no significant difference in any parameter of lipid profile between the groups and within groups.

\section{Discussion}

We studied 95 CWE with a mean age of 7.36 \pm 2.81 years (45 were on Valproic acid, 34 on Phenytoin and 16 were on combination therapy) and 50 healthy controls with mean age of $6.27 \pm 2.73$. A study done by Pooja Dewan et al [10] on effect of phenytoin and valproate therapy on serum lipid level and liver function tests included seventy-nine children with a mean age of $7.5 \pm 44$ years ( 27 in valproate group, 25 in phenytoin group and 27 in control group).

Similarly, in the study by Anju Aggarwal et al [11] on effect of Carbamazepine on Serum Lipids and Liver Function Tests, 56 children ( 28 cases and 28 controls) were included. Mean age was $8.3 \pm 2.8$ years in patients and $8.4 \pm 2.6$ years in controls.

In our study, Generalised tonic clonic seizure was observed to be most frequent seizure type $(83.2 \%)$ followed by simple partial seizure $(11.6 \%)$ and myoclonic type of seizure (4\%). Pooja Dewan et al [10] found generalised seizure in $74 \%$, localised in $22.2 \%$ and myoclonic in $3.7 \%$ of valproate group and $88 \%, 12 \%$ and $0 \%$ respectively in children on phenytoin. Whereas, Anju Aggarwal et al [11] observed partial seizure with secondary generalization in $43 \%(n=12)$, complex partial seizure in $46 \%(n=13)$ and simple partial seizure in $11 \%(\mathrm{n}=3)$.

In our study, all epileptic children had been treated for at least 3 months with either phenytoin alone, in a dose ranging from 5 to $10 \mathrm{mg} / \mathrm{kg} / \mathrm{d}$ (mean dose $7.14 \pm 0.31$ $\mathrm{mg} / \mathrm{kg} / \mathrm{d}$ ) or valproate alone, in a dose ranging from 15 to $35 \mathrm{mg} / \mathrm{kg} / \mathrm{d}$ (mean dose $27.3 \pm 6.3 \mathrm{mg} / \mathrm{kg} / \mathrm{d}$ ). This was comparable to the study conducted by Pooja Dewan et al [10] in which all epileptic children had been treated for at least six months with either phenytoin alone, in a dose ranging from 3 to $8 \mathrm{mg} / \mathrm{kg} / \mathrm{d}$ (mean dose $5.4 \pm 1.2 \mathrm{mg} / \mathrm{kg} / \mathrm{d}$ ), or valproate alone, in a dose ranging from 10 to 31.4 $\mathrm{mg} / \mathrm{kg} / \mathrm{d}$ (mean dose $20.2 \pm 6.6 \mathrm{mg} / \mathrm{kg} / \mathrm{d}$ ) and in the study done by Anju Aggarwal et al[11], children on AED for at least 3 months were included.

We did not find any significant difference in any parameter of lipid profile with respect to drug administration. Geda 
Research Article

G. et al [12] showed that valproic acid therapy did not change serum lipids, vitamin $\mathrm{B} 12$ and folic acid concentrations. Similarly, in the study conducted by Yalçin E et al [13], no significant differences in total cholesterol (TC), triglycerides (TG), low-density lipoprotein cholesterol (LDL-C) or very low-density lipoprotein cholesterol (VLDL-C) was found between all groups.

Verrotti A, et al [14] demonstrated that the effects of antiepileptic drugs on serum lipids and lipoproteins are transient and reversible.

A significant difference in variance between the cases and control group in serum Triglycerides, LDL-C and VLDL-C was noted in our study.

And The t-test indicated a significant difference in means among cases and controls in HDL-C, LDL-C and Risk Ratio .

Children receiving phenytoin had higher mean HDL-C and LDL-C, than the control and valproic acid group in one study [10] . Franzoni E et al [15], Berlit $\mathrm{P}$ et al [16] and Pelkonen $\mathrm{R}$ et al [17] showed similar results.

Pita-Calandre E et al [18] found that carbamazepine treated subjects showed specifically an increase in HDL2 lipoprotein cholesterol whereas phenytoin treated subjects showed specifically an increase of triglycerides.

Whereas Nikkila EA et al [19], O'Neill B et al [20] observed an elevation of high-density lipoprotein (HDL) in epileptic patients treated with phenytoin.

The effects on the serum lipid profile of long-term treatment with hepatic-enzyme-inducing antiepileptic drugs (such as carbamazepine and phenobarbital) are probably not beneficial as regards risk of atherosclerosis-related disease.

\section{Conclusion}

Keeping in view the risk of deranged lipid profile and subsequent atherosclerotic related disease in the long term, we recommend routine and sequential monitoring of lipid profile in children taking AEDs. However, to substantiate our results, we suggest long term studies on a bigger sample size for formulating guidelines or protocols.

\section{Funding: Nil}

Conflict of interest: Nil

Permission from IRB: Yes

\section{References}

1. Epilepsy: A manual for physician by WHO.SEAMENT-134:1-22.

2. Beilmann A, Napa A, Soot A,Talvik I, Talvik T. Prevalence of childhood epilepsy in Estonia. Epilepsia $.1999 ; 40: 1011-1019$

3. Sidenvall R, Forsgren L, Heijbel J. Prevalence and characteristics of epilepsy in children in Northern Sweden. Seizure .1996 Jun;5(2):139-46 .

4. Sridharan R, Murthy BN. Prevalence and pattern of epilepsy in India.Epilepsia.1999 May;40(5):631-6.

5. Nicoletti $A^{1}$, Reggio A, Bartoloni A, Failla G, Sofia V, Bartalesi F, Roselli M, Gamboa H, Salazar E, Osinaga R, Paradisi F, Tempera G, Dumas M, Hall AJ. Prevalence of epilepsy in rural Bolivia. A door to door survey.Neurology.1990 Dec 10; 53(9):2064-9.

6. Christianson AL, Zwane ME, Manga P, Rosen E, Venter A, Kromberg JG. Epilepsy in rural South Africa childrenprevalence ,associated disability and management. S Afr Med J.2000 Mar;90(3):262-6.

7. Moore TJ, Weiss SR, Kaplan S, Blaisdell CJ. Reported adverse drug events in infants and children under 2 years of age. Pediatrics. 2002 Nov;110(5): e53-7.

8. Miura H. Zonisamide monotherapy with once-daily dosing in children with cryptogenic localization-related epilepsies: clinical effects and pharmacokinetic studies.Seizure.2004 Dec;13 Suppl,1:S17-23;Discussion S24-5.

9. Friedewald WT, Levy RI, Fredrickson DS. Estimation of the Concentration of Low-Density Lipoprotein Cholesterol in Plasma, Without Use of the Preparative Ultracentrifuge: Clin Chem. 1972 June; 18(6): 499-502.

10. Dewan P, Aggarwal A, Faridi MM. Effect of phenytoin and valproic acid therapy on serum lipid level an liver. Indian Pediatr. 2008 Oct;45(10):855-8

11. Aggarwal A, Kumar M, Faridi MM. Effect of Carbamazepine on Serum Lipids and Liver Function Tests. Indian Pediatr. 2005 Sep; 42(9):913-8.

12. Geda G, Çasken H, Icagasioglu D. Serum lipids, vitamin B12 and folic acid levels in children receiving long-term valproate therapy.Acta Neurol Belg. 2002 Sep;102(3):122-6 
13. Yalçin E, Hassanzadeh A, Mawlud K.The effects of long-term anticonvulsive treatment on serum lipid profile. Acta Paediatr Jpn.1997 Jun;39(3):342-5

14. Verrotti A, Basciani F, Domizio S, Sabatino G, Morgese G, Chiarelli F. Serum lipids and lipoproteins in patients treated with antiepileptic drugs. Paediatr Neurol.1998 Nov; 19 (5): 364-7.

\section{Emilio Franzoni, Marina Govoni, Sergio} D'Addato, Stefano Gualandi, Zina Sangiorgi, Gian CarloDescovich' Gian Paolo Salvioli. Total cholesterol, high density lipoprotein cholesterol and triglycerides in children receiving antiepileptic drugs. Epilepsia. 1992 Sep; 33(5): 932-5.

16. Berlit P, Krause KH, Heuck CC, Shellenberg B. Serum lipids and anticonvulsants. Acta Neurol Scand. 1982 Sep; 66(3): 328-34.
17. Pelkonen R, Fogelholm R, Nikkila EA. Increase in serum cholesterol during phenytoin treatment. Br Med J. 1975 Oct 11;4 (5988): 85.

18. Pita-Calandre E, Rodríguez-López CM, Cano MD, Peña-Bernal M. Serum lipids. lipoproteins, and apolipoproteins in adult epileptics treated with carbamazepine, valproic acid, or Phenytoin. Rev Neurol.1998 Nov;27(159):785-9.

19. Nikkilä EA, Kaste M, Ehnholm C, Viikari J. Increase of serum high-density lipoprotein in Phenytoin users. Br Med J. 1978 July 8; 2(6130):99-99.

20. O’Neill B, Callaghan N, Stapleton M, Molloy W. Serum elevation of high density lipoprotein (HDL) cholesterol in epileptic patients taking carbamazepine or phenytoin. Acta Neurol Scand. 1982 Feb;65(2):104-9.

\section{How to cite this article?}

Nadkarni J, Uikey D, Sharma U, Dwivedi R. Effect of Antiepileptic drugs on lipid profile in children with Epilepsy.Int J Med Res Rev 2014;2(2):119-123. doi:10.17511/ijmrr.2014.i02.09. 